\title{
Pemahaman tentang Budaya Supporter Sepakbola (Kajian Fenomenologi Berdasarkan Kasus Supporter Sepakbola Aremania Malang) ${ }^{1}$
}

\author{
Harun Ahmad \\ Program Studi Pendidikan Bahasa dan Sastra Indonesia \\ IKIP Budi Utomo Malang \\ harun.a.sangaji@gmail.com \\ Yahmun \\ Program Studi Pendidikan Bahasa Inggris \\ IKIP Budi Utomo Malang
}

\begin{abstract}
The research was motivated by the debate over cultural affairs of football supporters in both theoretical and empirical levels. From these debates there are a number of relevant problems to be studied further, especially emic perspective, ie with respect to (1) the concept of football supporters socially constructed and is rooted in the view Aremania, (2) typology of football supporters among Aremania accordance with the concepts and categories as well as the basic values of what used as the basis of concepts and categorization, (3) football supporter culture is used as the common reference Aremania and the factors that influence it. This research is a qualitative phenomenological, with three methodological implications, namely (1) to put the focus on the observation and study of the social practices that take place as rergularitas daily, (2) to notice cultural aspects or dimensions that surround the practice of social actors, and (3) to put the actors as knowledgeable agents of social practice, it is necessary for the analysis of strategic conduct. The experiment was conducted in Malang, East Java, precisely in the city of Malang, with field activities for one year, ie since the beginning of October 2011 to October 2012, and obtained the following results. First, Aremania football fans everywhere characterized as football fans in general. This is consistent with the conception of football supporters who claim that football fans are different from other fans because of the audience but also have high levels of bigotry against high club. However, it is wrong to equate Aremania with other football fans. Because, unlike fanatical fanaticism of Aremania of the other football fans. But the ethics are culture fanatic fans who wanted to be constructed by Aremania. Fanatical but should not be to the extent of harm to others. There is respect for the values of humanity while keeping the honor and dignity of the people of Malang. Secondly, based on the emic perspective, football fans have covered broader meaning than merely watching football. Devoting time and energy maximize resources belonging to supporting his favorite club is also interpreted as a football supporter culture. Even time consuming as well as the soul-body to support his/her favorite team is also defined as the culture of football fans. Third, even football and it's important for Arema people of Malang, but its primacy over the instrumental is more pride and underwriters including a source of honor and dignity of Malang people. This is consistent with the ethos of the culture of the Malang who "comes first" matter of honor and dignity.
\end{abstract}

Keywords: review of phenomenology, culture football fans Aremania

Sepakbola adalah olahraga paling populer di dunia, sehingga menjadi suatu hal yang wajar jika kejuaraan sepakbola yang melibatkan seluruh negara di dunia dinamai World Cup tanpa harus menyebut jenis olahraganya. Sepakbola termasuk olahraga tontonan yang terkait erat dengan olahraga populer yang melibatkan sekumpulan orang dalam jumlah besar. Istilah populer mengacu pada permainan yang "produced by the people, returns to the people, like 'folk music', in the form of spectacles produced for the people" (Bourdieu, 1993:433). Unsur sosial-psikologis akan sangat menonjol ketika sepakbola mengonstruksi keterlibatan orang dalam jumlah massal, terutama keterlibatan massa dari kelas menengah ke bawah. Eduardo Galeano, ${ }^{1}$ seorang jurnalis sepakbola menyatakan: "Football is a working class sport". Hal ini mengisyaratkan bahwa sepakbola merupakan salah satu

1 Hasil Penelitian Fundamental, dibiayai Direktorat Jenderal Pendidikan Tinggi, Kementerian Pendidikan dan Kebudayaan, Dana DIPA Kopertis Wilayah VII Jawa Timur, Tahun 2012. 
bentuk budaya populer.

Di negara-negara Eropa, suporter sepakbola dikaitkan dengan kelas menengah ke bawah dan seringkali dekat dengan kebrutalan, seperti hooligan di Inggris dan tifosi di Italia. King (1997) dalam penelitiannya menyebutkan bahwa media juga berperan membentuk citra suporter seperti itu. Ia juga menemukan bahwa para hooligan di Inggris justru senang dengan citra bentukan media karena mereka akhirnya memiliki alasan untuk bertindak brutal dan menyerang polisi yang dianggap sebagai musuh kaum kelas menengah ke bawah dan pekerja. Dari citra ini juga chant atau nyanyian suporter lebih merupakan umpatan daripada dukungan terhadap klub. ${ }^{2}$ Di Indonesia, citra seperti ini juga seringkali diatributkan kepada pendukung sepakbola. Kerusuhan-kerusuhan yang diakibatkan oleh ulah suporter sepakbola membuat banyak orang menganggap sepakbola di Indonesia hanya berisi berita kekalahan dan atau kerusuhan suporter.

Keterlibatan orang dalam jumlah massal mengisyaratkan bahwa sepakbola merupakan olahraga spectacle (tontonan). Karakter tontonan itu sendiri adalah: "First, attention is all important, it must be attracted and maintained. Second, vision is arranged, organized, disposed within various hegemonic visual regimes, the most influential and pervasive of which is that of capitalism. Third, everything is (potentially) reduced to the status of commodity and there is an emphasis on necessary, repetitive and mobile (visual) consumption. Fourth, the subject-as-spectator relates to the social and the self through the consumption of commodities" (Schirato, 2007:104). Karakter tontonan tersebut menunjukkan bahwa sepakbola sebagai sebuah tontonan selayaknya menampilkan sesuatu yang menarik agar mampu menyedot massa dalam jumlah yang banyak.

Pertandingan sepakbola tidak hanya permainan, tetapi juga sekumpulan aspek-aspek yang membuat sepakbola ibarat sebuah drama. Emosi suporter tidak hanya dibangun dengan keterikatan asal tetapi juga faktor-faktor lain. Sepakbola modern akhirnya erat dengan aspekaspek politik, ekonomi, dan sosial-budaya yang menyertainya. Pendukung klub Real Madrid, misalnya, tidak hanya terlihat di Madrid saja tetapi juga dari seluruh dunia karena citra Real Madrid yang dibangun menarik perhatian orang-orang di luar Madrid.

Di Kota Malang, sebagaimana halnya beberapa kota besar di Indonesia, euforia penonton terhadap sepakbola juga tidak kalah hebat dibandingkan dengan yang terlihat di luar negeri. Masa Aremania dalam mendukung Arema Indonesia ketika bertanding juga mampu mempertontonkan sebuah pertunjukkan yang sangat menarik, sebagaimana dapat disaksikan terutama dalam pertan-dingan home Arema. Aremania membuat atraksi pertandingan yang menarik selain pertandingan sepakbola itu sendiri. Pukul 12.00 daerah di sekitar Stadion Kanjuruhan, kandang Tim Singo Edan (julukan Arema Indonesia) mulai didekati Aremania. Pukul 14.00 Sektor Ekonomi (daerah penonton kelas ekonomi) mulai ramai disesaki Aremania. Pukul 14.30 Tribun VIP mulai dipadati. Pukul 15.00 Dirigen Aremania tiba di stadion. Dirigen di Utara adalah Yuli Sumpil, dan Karpet di sebelah Selatan. Mereka memulai semacam latihan soraksorai, lagu dan dansa yang terus berlang-sung sampai akhir pertandingan. Pukul 15.20 para pemain memasuki lapangan untuk pemanasan. Saat itu nama setiap pemain dipanggil satu persatu oleh Ovan Tobing selaku announcer lengkap dengan nomor punggung masingmasing. Semuapemain Aremamenerimastanding ovation meriah dari Aremania. Pukul 15.25 semua Aremania berdiri, mengangkat syalnya dan dengan kompak menyanyikan lagu 'Padamu Negeri'. Pukul 15.30 pertandingan dimulai. Ada bermacam-macam lagu dinyanyikan Aremania sambil menirukan gerak-gerik dirigen. Selama dansa itu, Aremania melambaikan tangan dan syal atau bendera sambil mengikuti irama lagu. Gerakan atraktif dan kreatif menghiasi permainan Arema sepanjang pertandingan. Pukul 17.30 pertandingan berakhir, dan Arema kalah. Walaupun Arema kalah, Aremania tetap sopan, tertib, dan tidak membuat keonaran sepanjang perjalanan pulang ke rumah masingmasing. Sebuah pemandangan yang sangat menakjubkan.

Perubahan sikap dan perilaku Aremania dari citra supporter brutal, bringas, dan anarkis ke citra suporter teladan yang kreatif dan atraktif memantik sejumlah pertanyaan. Apakah perubahan sikap dan perilaku Aremania tersebut merupakan wujud kepeduliannya terhadap Arema sebagai kesebelasan profesional yang sekaligus menuntut Aremania bersikap dan berperilaku profesional? Ataukah sikap dan perilaku positif (kreatif dan atraktif) Aremania terhadap Arema, hanya sebatas faktor hiburan, ekstasi, dan bahkan kedangkalan ritual sebagaimana tesis Bauldrillard (1988) tentang ekstasi dan kedangkalan ritual dalam upacara menonton pertandingan sepak bola? Ataukah bentuk dukungan tersebut merupakan ekspresi 
kesadaran Aremania sebagai wujud pemahaman mereka akan nilai, asumsi, definisi, ukuran, logika, dan bahkan teori? Ataukah ada faktor lain yang menyebabkan wujud dukungan Aremania terhadap Arema berkategori demikian?

Ada sejumlah pertanyaan yang relevan diajukan untuk diteliti. Pertanyaan-pertanyaan tersebut dipandang perlu dijawab, karena perdebatan di seputar perubahan perilaku Aremania dari anarkis ke supporter teladan yang kreatif dan atraktif pada tataran teoretik maupun empirik, lazim bertolak dari perspektif para ahli atau teoretisi, dan belum berdasarkan konsep dan perspektif Aremania itu sendiri. Aremania selama ini seringkali dipersepsi oleh masyarakat terutama para peneliti sebagai "orang yang dipelajari" untuk disimpulkan siapa dan bagaimana mereka, bukan sebagai "orang tempat kita belajar" tentang Aremania selaku suporter sepakbola. Yang cenderung dipakai adalah perspektif etik, bukan perspektif emik. Inferensi ditarik berdasarkan angka-angka hasil observasi, sejalan dengan logika dan perspektif para peneliti yang mempelajarinya. Kecenderungan seperti itu juga terjadi pada mereka yang tergolong substantivist, dan lebihlebih lagi di kalangan ahli yang tergolong formalist. Beberapa kajian tentang Aremania juga bertolak dari hasil mempelajari Aremania secara demikian itu. Inferensinya berdasarkan angkaangka dan berapa jumlah korban akibat tindakan anarkis Aremania pada masing-masing kasus yang "dipelajari". Prokontra ihwal perubahan perilaku Aremania dari tindakan anarkis ke supporter teladan juga mencerminkan "perang penafsiran" berdasarkan perspektif para peneliti itu sendiri. Dunia Aremania menurut perspektif pelakunya sendiri (perspektif emik) dibiarkan berada "nun jauh di sana", tak tersentuh, masih laksana sebuah kotak hitam yang belum dibuka untuk didengar "kesaksiannya".

Atas dasar itu penelitianinimengambil posisi untuk mencoba memahami Aremania menurut perspektif (pandangan, asumsi, nilai, dunia ide, dan bahkan teori) Aremania itu sendiri. Posisi demikian itu diambil berdasarkan keyakinan bahwa apa pun yang terpola dalam kebiasaan Aremania menyaksikan pertandingan Arema, termasuk juga yang berkaitan dengan budaya mereka, tentu berada dalam kerangka makna yang terkonstruksi di alam pikiran mereka masing-masing. Hal tersebut tentu saja tidak terlepas dari social framework yang melembaga dan melingkungi mereka. Oleh karena itu, upaya memahami budaya Aremania, berpola sama atau berbeda satu sama lain, dipandang perlu untuk beranjak dari dunia ide dan pemahaman Aremania itu sendiri, yakni berdasarkan dunia makna beserta konstruksi sosial-budaya yang memang hidup di kalangan Aremania itu sendiri selaku agen/pelaku budaya. Dengan demikian, yang dipandang penting dalam penelitian ini bukanlah pada how much melainkan lebih pada what is yang berkenaan dengan budaya Aremania. Pusat perhatiannya tertuju kepada bagaimana Aremania memaknakan apa yang mereka sebut dengan suporter, dasar pemaknaan dan kategorisasinya seperti apa, serta dunia rasionalitas macam apa yang melatarbelakangi. Dengan demikian menonton pertandingan sepakbola tetap ditempatkan sebagai tema sentral dalam penelitian ini. Meskipun demikian, konsep suporter sepakbola mungkin saja lebih luas cakupannya, bukan sekedar dalam konteks menonton atau menyaksikan pertandingan sepak bola. Dengan demikian, permasalahan pokok penelitian ini, adalah: (1) Bagaimanakah konsep suporter sepakbola secara luas yang terkonstruksi (socially constructed) dan berakar dalam pandangan Aremania? Apakah cakupan maknanya sematamata dalam konteks sepakbola atau lebih luas dari itu?; (2) Bagaimanakah tipologi suporter sepakbola di kalangan Aremania sesuai dengan konsep dan kategorinya? Nilai dasar apakah yang dijadikan pijakan untuk konsep dan kategorisasi tersebut?; dan (3) Budaya suporter sepakbola seperti apakah yang dijadikan sebagai referensi umum? Apa yang membuatnya demikian? Apakah sumbernya semata-mata bersifat kegemaran ataukah ada sumber-sumber lain yang bersifat nonkegemaran? Tujuannya adalah untuk mengeksplorasi bagaimana sesungguhnya budaya suporter sepakbola yang hidup dan terpola di kalangan Aremania. Dari hasil eksplorasi tersebut diharapkan diperoleh suatu gambaran umum (untuk tujuan deskripsi) tentang (1) konsep suporter sepakbola secara luas, termasuk tujuannya, yang berakar pada pandangan Aremania, (2) tipologi budaya supporter sepakbola, khususnya dalam konteks sepakbola berdasarkan konsep dan kategorisasi, dan (3) budaya supporter sepakbola yang dijadikan preferensi umum di kalangan Aremania.

\section{METODE}

Penelitian ini mengambil posisi untuk memahami budaya Aremania berdasarkan perspektif Aremania itu sendiri. Artinya, 
berupaya memahami budaya Aremania menurut sudut pandang, asumsi, definisi, ukuran, logika, dan bahkan teori Aremania itu sendiri. Itulah yang populer dengan sebutan perspektif emik, sebagai kebalikan daripersepektifetik. Hal tersebut sesuai dengan keyakinan bahwa Aremania juga termasuk knowledgeable agent, yang tahu apa yang dilakukan dan mengapa melakukannnya. "To be a human being", kata Giddens (1984:3) "is to be a purposive agent, who both has reasons for his or her activities and is able, if asked, to elaborate discursively upon those reasons...". Oleh karena itu, orang awam sekalipun, bagi Giddens termasuk juga social theorist, yang teorinya diterapkan dalam kehidupan mereka sehari-hari (Faisal, 1996).

Atas dasar itu, rasanya sangat relevan dan beralasan menggunakan pendekatan kualitatif untuk dapat memahami secara memadai berbagai rupa praktek sosial, termasuk juga budaya Aremania yang menjadi pusat perhatian penelitian ini. Karakteristik pokok pendekatan ini ialah mementingkan makna, konteks, dan perspektifemik; prosespenelitianlebihberbentuk siklus daripada linear, karena pengumpulan dan analisis data berlangsung secara simultan; lebih mementingkan kedalaman ketimbang keluasan cakupan penelitian; observasi dan wawancara mendalam bersifat sangat utama dalam proses pengumpulan data, serta peneliti itu sendiri yang merupakan instrumen utama.

Pendekatan penelitian kualitatif yang digunakan dalam penelitian ini menerapkan strategi sebagai berikut. Pertama, langkah awal penelitian memusatkan perhatian pada kegiatan observasi, mengamati berbagai ragam praktek yang terpola dan terkait dengan budaya Aremania termasuk menyimak kata-kata atau ungkapan-ungkapan relevan yang terkait pandangan Aremania juga diperoleh, terutama dari hasil merekam ungkapan sehari-hari yang merefleksikan jalan pemikiran, proposisi, teori, dalil sehari-hari mereka mengenai tugas/ kewajiban beserta tujuan mereka menjadi suporter sepakbola dan bagaimana seharusnya dijalani. Langkah pertama ini dimaksudkan untuk memperoleh gambaran tentang "peta" praktek sosial yang relevan dan berkaitan dengan budaya dalam kehidupan sehari-hari Aremania yang menjadi situs penelitian; apa saja atau mana saja yang berlaku umum, serta apa saja atau mana saja yang berlaku khusus bagi orang atau kelompok tertentu di kalangan Aremania. Potret "peta lapangan" semacam itu dapat diibaratkan semacam "tabel" dalam tradisi penelitian kuantitatif (Fasial, 1990; 1996). Ia merupakan fokus kajian, apakah untuk tujuan deskripsi semata ataukah untuk tujuan pengembangan teori (theory building); itu disesuaikan dengan rumusan masalah dan tujuan penelitian. Kedua, hasil observasi yang memerlukan pemahaman lebih lanjut untuk menemukan makna di balik suatu praktek sosial digali dengan melakukan indepth interview. Informasi dari informan lain bersifat melengkapi (bila dipandang perlu), khususnya sebagai informasi awal mengenai 'siapa" dan "bagaimana" agen suatu praktek sosial tertentu (agar tidak mudah dibohongi dalam proses penggalian data dari agen praktek sosial). Langkah ini sebagai bagian dari upaya mencari makna (tafsiran) terhadap "tabel" yang ditemukan dari (hasil pelaksanaan) strategi yang disebutkan pertama.

Ketiga, menerapkan prinsip dan teknik komparasi secara konstan sepanjang proses penelitian, baik dalam rangka menemukan "peta" praktek sosial beserta spesifikasi agen maupun dalam rangka menemukan makna di balik suatu praktek sosial. Dengan menerapkan prinsip dan teknik tersebut, strategi yang disebutkan pertama dan kedua tadi menjadi tidak mungkin berlangsung linear, melainkan "bolak-balik", interaktif dan berbentuk siklus; karenanya, kegiatan pengumpulan dan analisis data juga pada dasarnya berlangsung simultan sepanjang proses penelitian berlangsung (intrim analysis) sebagaimana diajukan Huberman dan Miles (1984:429). Proses "sampling" juga mengikuti hasil penerapan prinsip dan teknik komparasisecarakonstantersebut;pengumpulan dan analisis data akan berhenti pada suatu titik tertentu ataukah perlu penelusuran dan penggalian lebih lanjut bergantung pada hasil komparasi secara konstan yang dilakukan ketika penelitian ini berlangsung. Komparasi secara konstan yang diterapkan dalam penelitian ini bukanlah dalam maknanya yang sempit (analisis komparasi terhadap individu/ kelompok sasaran studi), tetapi dalam maknanya yang luas, yaitu menunjuk pada proses penggalian data secara terus menerus guna melacak letak persamaan dan atau perbedaan atas suatu domain, semacam penerapan structural question yang diajukan Spradley (1979:117-118).

\section{HASIL DAN PEMBAHASAN}

\section{Makna Suporter Sepakbola dalam Pandangan Aremania}

Aremania adalah sebutan untuk komunitas suporter klub sepakbola Arema Indonesia. 
Awalnya Aremania adalah supporter sepakbola yang sangat fanatik dalam mendukung Arema, sehingga seringkali melakukan tindakantindakan anarkis. Oleh karena itu, citra yang terbangun dan melekat pada Aremania adalah kelompok suporter sepakbola paling "bringas", "brutal", dankejam. Namundemikian, citraburuk tersebut berubah seiring perubahan perilaku Aremania yang tidak lagi mengedepankan aksiaksi heroik yang brutal dan anarkis tapi lebih pada aksi-aksi yang kreatif dan atraktif, lebih mengedepankan unsur keindahan.

Di kalangan Aremania terdapat sebuah ungkapan khas yang selalu mereka ucapkan ketika bertemu sesama Aremania di mana saja. Apalagi ketika mendukung Arema Indonesia saat bertanding, ungkapan ini akan selalu terdengar. Ungkapan itu berbunyi: "Salam Satu Jiwa, Arema".

Apa makna yang terkandung di balik ungkapan tersebut? Apakah ia sekedar ungkapan simbolis atau simbol status pemiliknya? Atau adakah makna lain yang lebih jauh lagi? Apakah ungkapan itu suatu ungkapan simbolik yang "berbicara banyak" tentang siapa dan bagaimana pemiliknya? Apakah ungkapan tersebut merefleksikan suatu ide dasar yang mengalir dari pandangan hidup Aremania? Secara sederhana, dengan mudah dapat dikatakan bahwa ungkapan tersebut tidak lebih dari sekedar ungkapan keseharian khas anak muda di Malang. Argumennya bisa ditambah berdasarkan kenyataan sosok Aremania yang terkenal lugas, blak-balakan, dan tidak basabasi. Benarkah sesederhana itu jawabannya?

Hasil menyimak konstruksi sosial-budaya sehari-hari maupun interaksi antar Aremania (social interaction) ketika mendukung Arema (bersifat proporsional maupun bukan) ternyata memberi kemungkinan jawaban lain. Menyimak percakapan antar sesama Aremania terutama para "tokoh" yang menjadi panutan Aremania bertebaran berbagai macam pernyataan tentang apa sesungguhnya yang mereka cita-citakan. Sewaktu digali lebih jauh, jawabannya menjadi tunggalyakni bercita-cita membangun persatuan dan atau persaudaraan antar Arek Malang.

Cita-cita saya, pagar besi pembatas tribun dengan lapangan nanti tidak perlu ada lagi. Jadi kita menonton sepakbola dengan enak, tidak ada perkelahian, tidak ada suporter yang mengganggu pemain. Saya juga ingin semua golongan bisa bersatu di sini. Kaya atau miskin, laki-laki atau perempuan, Cina atau bukan Cina, pejabat atau orang biasa,
Islam atau Kristen, di sini semuanya sama, bersaudara. $^{3}$

Kami (Aremania) datang ke sini (stadion) tidak sekedar menonton sepak bola, "Sam", tetapi lebih dari itu yakni membangun persatuan dan persaudaraan sebagai sebuah identitas bagi Arek Malang. ${ }^{5}$

Konstruksi pemikiran yang teridentifikasi di atas menyiratkan bahwa Aremania menginginkan agar sepakbola tidak lagi menjadi ajang pertikaian, permusuhan apalagi perkelahian, tetapi lebih sebagai ajang membangun persatuan dan persaudaraan. Siapa saja yang datang ke Stadion untuk menyaksikan pertandingan Arema Indonesia adalah saudara. Tidak ada stratifikasi sosial, perbedaan jenis kelamin, perbedaan suku, ras (etnis), bahasa, perbedaan agama, tua maupun muda, lakilaki atau perempuan, semuanya sama, samasama anak bangsa. Menonton pertandingan sepakbola dengan demikian dalam pandangan Aremania adalah ajang membangun persatuan dan persaudaraan sesama anak bangsa.

Muncul kesadaran bahwa tidak ada manfaat lebih bagi sebuah perseteruan antar suporter jika kebanggaan itu berakhir dengan tidakan destruktif. Bahkan, dalam hal ini klub sudah pasti akan merasa dirugikan akibat sanksi. Klub akan mengeluarkan anggaran lebih untuk membayar denda. Klub juga akan dikenai denda larangan main di kandang sendiri di laga selanjutnya atau bermain tanpa penonton. Tentu selain mengeluarkan biaya lebih, klub juga terancam tidak akan mendapat pemasukan dari hasil penjualan tiket penonton. Itu sebabnya, dari dalam hati setiap Aremania yang paling dalam muncul cita-cita perdamaian, menghentikan perselisihan dengan melupakan sejarah kelam masa lalu.

Kesadaran Aremania untuk membangun budaya persatuan dan persaudaraan sebagai sebuah identitas dilatarbelakangi oleh keinginan untuk membangun Aremania yang sehat dan dewasa sekaligus meminimalisasi dan bahkan mengeliminasi tindak kekerasan yang acapkali dilakukan oknum Aremania yang tidak dapat mengendalikanemosiketikamendukung Arema. Membangun persaudaraan sejati sebagai sebuah identitas bersama semua anak bangsa dengan lebih mengedepankan keindahan bukanlah hal yang mudah. Akan tetapi, setidaknya Aremania telah memulainya. Mulai membangun sebuah identitas suporter yang tidak lagi berlandaskan kebencian dan rasa tidak suka kepada yang lain, 
tapi lebih pada sebuah identitas yang selalu mengedepankan nilai-nilai persaudaraan sejati bagi semua anak bangsa. Sebab sepakbola adalah bahasa universal. Sepakbola adalah wahana terbaik membangun persaudaraan sejati tanpa mengenal batas, persau-daraan tanpa batas, tidak mengenal warna kulit, bahasa, ataupun agama.

Cita-cita luhur Aremania tersebut sejalan dengan konsepsi yang jamak diterima bahwa manusia sebagai makhluk budaya akan selalu berupaya membangun identitas dalam relasi sosial dan kultural untuk menegaskan posisi individual dan sosial suatu komunitas di hadapan orang atau komunitas lain. Identitas adalah representasi diri melalui mana seseorang atau masyarakat melihat dirinya sendiri dan bagaimana orang lain melihat mereka sebagai sebuah entitas sosial-budaya. Identitas adalah produk budaya yang dalam praktek sosial berlangsung demikian kompleks, namun kadangkala atau bahkan seringkali direduksi sebagai sesuatu yang pasti, utuh, stabil, dan tunggal. ${ }^{6}$ Identitas budaya dibangun dengan asumsi persamaan dan perbedaan. Persamaan suatu komunitas akan mengikat mereka dalam identitas tertentu sebagai satu kesatuan sosial dan kultural yang mengada secara unik (sebagai kami) atas dasar berbagai perbedaan dengan komunitas lain (sebagai mereka). Dengan demikian, suatu masyarakat membangun identitas mereka atas dasar persamaan di antara anggota masyarkat itu sendiri sekaligus atas dasar perbedaannya dengan masyarakat lain. Sampai batas tertentu identitas budaya turut membangun kohesi dan solidaritas sosial dalam struktur internal suatu masyarakat sesama pemilik suatu identitas budaya. ${ }^{7}$

Pembentukan identitas budaya sejatinya tidak sesederhana itu, karena faktanya jauh lebih kompleks dari apa yang bisa dibayangkan. Masalahnya, kebudayaan suatu masyarakat selalu bersifat heterogen bahkan pada tingkatnya yang paling sederhana sekalipun. Apa yang diasumsikan sebagai persamaan ternyata tidak lain dari pecahan-pecahan keberbagian yang coba disatukan dalam sebuah produk atau konstruk budaya yang dibayangkan sebagai "inti" sebuah kebudayaan. Artikulasi sebuah identitas dengan demikian sesungguhnya mereduksi kompleksitas dan heterogenitas kebudayaan. Pada gilirannya asumsi tentang persamaan ini menjebak proyek identitas ke dalam tendensi esensialis. Identitas bukan saja menuntut artikulasi melalui mana subjek menyatakan dirinya secara terbuka sebagai suatu entitas sosial dan budaya, melainkan juga mengan-daikan ditemukannya suatu esensi, sesuatu yang utuh, stabil, tetap, dan tunggal. Pada titik inilah proyek identitas terjebak dalam satu pengandaian bahwaidentitas budaya adalah sesuatu yang sudah ada dan terberi, sehingga tugas subjek tinggal menemukan identitas itu.

Perkembangan masyarakat Kota Malang yang begitu kompleks dengan berbagai bentuk interaksi membentuk sebuah tatanam sosial yang memiliki ciri dan pola kehidupan yang berbeda. Kendati demikian, kehadiran komunitas Aremania adalah sebuah keniscayaan dan tidak bisa dihindari dalam kehidupan bermasyarakat khususnya di Kota Malang. Dalam konteks ini kemunculan dan keberadaan Aremania bisa dipahami tidak bersifat sementara, terorganisasi sesuai konsensus dan kepentingan yang terajuk pada setiap individu Aremania.

Aremania sebagai kelompok sosial cenderung terkonstruksi karena tekad dan minat yang sama untuk membentuk sebuah ikatan emosional. Tidak berbeda jauh dengan kelompok yang sering disebut sebagai kerumunan (crowd). Kerumunan sering terjadi pada suatu tempat tertentu yang memiliki pola tertentu dengan manampilkan sebuah ciri khas dan identitas tertentu bersifat kebetulan yang melahirkan sebuah interaksi dengan perasaan emosional yang sama terhadap sebuah identitas. Karakteristik sebuah kerumunan adalah pola kelompok sosial hanya memiliki rentang waktu yang sangat singkat, sebab keber-adaan kerumunan ditentukan oleh eksistensi individu yang sedang berkumpul. Selain itu kerumunan tidak memiliki struktur kepemimpinan atau struktur organisasi yang jelas. Kedudukan individu dalam kelompok sosial ini adalah sama karena di dalamnya tidak ada sistem pelapisan.

\section{Tipologi Budaya Suporter Sepakbola Arema- nia}

Ketika menyaksikan pertandingan Arema baik kandang maupun tandang bisa disaksikan sebagian Aremania yang tergolong super fanatik. Mereka tidak sekedar menjadi penonton yang setia dan tertib dalam menyaksikan pertandingan Arema. Lebih dari itu, mereka bermanuver dan sangat atraktif yang disemangati oleh panggilan jiwa untuk mendukung Arema agar mampu memberikan hasil yang terbaik. Oleh karena itu, mereka akan berupaya mengoptimalkan sumbersumber daya (tenaga, waktu, uang, dan lain-lain) yang tersedia atau dipunyai. Disemangati oleh 
jiwa optimalisasi sumber daya yang dipunyai. Kualitas "tahan bantingan" juga melekat dalam diri mereka. Rintangan-rintangan alam seperti hujan lebat, terik matahari, dan bahkan gelap malam acapkali tidak "digubris", dikalahkan oleh kemauan dan semangat pantang mundur, pantang menyerah yang memang tinggi demi Arema. Mereka mempersonifikasikan Arema sebagai diri mereka, sehingga jika Arema menang dalam sebuah pertandingan berarti juga kemenangan bagi Aremania.

Tipologi Aremania yang pertama ini relatif sedikit (tidak banyak) tetapi kehadiran mereka sangat memengaruhi suasana psikologis Aremania lainnya. Kelompok ini umumnya datang ke stadion dengan berpenampilan "aneh". Salah satu contohnya adalah penampilan Bowo. Sewaktu penelitian ini berlangsung Bowo juga datang dengan penampilan yang "aneh" itu, karena hampir seluruh tubuhnya mulai pusar sampai kepala dipasangi anting-anting tanpa baju. Suatu mode penampilan yang boleh dikatakan tidak lazim. Bahkan sebagian orang tidak berani melihat "dandanan" aneh seperti itu. Walau-pun begitu Bowo tetap merasa biasa saja. "... ora enek sing wani ndelok. Aku malah biasa ae, malah tak kongkon masangne pinku. Iki jenenge ekspresi, Sam, ha ha ha", begitu kata Bowo. Selain Bowo, ada juga beberapa Aremania yang berpenampilan "aneh" seperti itu tetapi mereka cukup menggunakan cat untuk melumuri sebagian badan mereka dengan lambang Arema dan Aremania.

Berdasarkan konsep dan kategori, budaya suporter Aremania dapat dibedakan ke dalam tiga kategori, yakni: (1) fanatik tapi beretika, (2) loyalitas tanpa batas, dan (3) tidak narsis tapi selalu eksis. Perbedaan kategori-tipologis tersebut berakar pada perbedaan perspektif di kalangan Aremania itu sendiri, khususnya dalam memaknai wujud dukungan terhadap Arema. Perbedaan perspektif dimaksud tercermin pada seperangkat pegangan atau pendirian yang dianut oleh para Aremania di masing-masing kategori. Mereka yang berbeda kategori juga berbeda pendirian yang dianut. Hal itu mengisya-ratkan adanya heterogenitas supporter di kalangan Aremania, meskipun mereka berada dalam ikatan komunitas dan lingkungan alam beserta sistem budaya yang sama.

Mengapa kenyataan yang demikian itu bisa terjadi? Apakah yang menjadi sumber dari heterogenitas supporter di kalangan Aremania? Bagaimanakah fenomena hetero-genitas supporter Aremania tersebut dapat dimengerti atau dipahami? Bagian ini secara khusus dimaksudkan untuk menemukan pemahaman teoretis, berdasarkan kenyataan empiris, yang bisa menjelaskan mengapa terjadi heterogenitas budaya supporter di kalangan Aremania. Untuk itu diperlukan pemahaman tentang siapa agen pada masing-masing kategori serta mengapa mereka menjadi agen budaya tersebut menurut perspektif agen budaya itu sendiri. Dengan demikian, sumber heterogenitas suporter ditelusuri dan diinterpretasikan berdasarkan kenyataan tentang siapa agen masing-masing kategori beserta dunia rasionalitas yang mendasari mengapa mereka menjadi agen suatu kategori budaya tertentu.

Hasil observasi awal peneitian ini mengisyaratkan ada kaitan erat budaya suporter Aremania denganlatarbelakangsosial-ekonomipendidikan. Budaya supporter "fanatik tapi beretika", misalnya, terlihat menonjol dan melekat pada mereka yang berasal dari keluarga yang kurang mampu secara ekonomi. Demikian juga budaya "loyalitas tanpa batas" sangat menonjol pada mereka yang latar belakang pendidikannya kurang. Sebalik-nya, budaya "tidak narsis tapi selalu eksis", terlihat sangat menonjol pada mereka yang latar belakang sosial-ekonomi-pendidikan tergolong cukup.

Atas dasar kenyataan tersebut secara hipotetik dapat dinyatakan bahwa penjelas dari heterogenitas budaya Aremania itu terletak pada bagaimana posisi sosial-ekonomi dan latar belakang pendidikan. Bila kenyataannya demikian, berarti sejalan dengan teori hasil belajar sosial (social learning), dan sedikit banyak juga sejalan dengan teori-teori yang tergolong determinisme ekonomi. Apakah posisi sosialekonomi beserta tempaan hasil belajar dalam keluarga dan lingkungan bisa sepenuhnya menjelaskan fenomena heterogenitas budaya Aremania? Apakah tidak ada kasus-kasus yang bersifat menyang-gah (negative case)?

Hasil observasi dan pelacakan lebih lanjut menunjukkan suatu kenyataan yang kian kompleks, karena ada berbagai rupa kasus penyanggah. Mereka yang tergolong berbudaya "fanatik tapi beretika", misalnya, posisi latar belakang sosial-ekonomi juga beragam. Selain berasal dari keluarga yang kurang mampu juga ada yang berasal dari keluarga yang cukup mampu. Bahkan ada pula yang berasal dari keluarga yang tergolong cukup kaya.

Tipe yang tergolong menonjol sebagai mainstream di masing-masing kategori budaya 
Aremania adalah tipe 1 yakni "fanatik tapi beretika", sebab jumlah agen yang tergolong berada pada tipe 1 memang cenderung lebih menonjol dibandingkan dengan mereka yang berada pada tipe yang lain. Oleh karena itu, wajar dan bisa dimengerti bila kesan awal (hasil observasi) memperlihatkan adanya keterkaitan budaya Aremania dengan latar belakang posisi sosial-ekonomi dan pendidikan mereka. Akan tetapi, dengan adanya kasus-kasus negatif, maka diperlukan suatu penjelasan lain, setidaktidaknya penjelasan tambahan yang bisa secara memadai menjelaskan sumber heterogenitas budaya Aremania.

Adakah penjelasan tambahan yang lebih memadai untuk menjelaskan sumber heterogenitas budaya Aremania? Apakah menonjolnya tipe 1 sebagai mainstream di masing-masing kategori budaya Aremania merupakan konsekuensi logis dari logika sosialekonomi dan pendidikan Aremania? Adakah logika lain (bersifat non-sosial-ekonomipendidikan) yang ikut bermain dalam diri Aremania? Bagaimanakan dengan kasus-kasus penyanggah (negative case) yang terdapat pada setiap kategori budaya Aremania? Mengapa Aremania mengambil "jalan berbeda", tidak sejalan dengan tipe menonjol yang menjadi mainstream? Adakah "benang merah" yang bisa menjelaskan semua itu? Berikut disajikan kasus Bowo, yang dalam penelitian ini merupakan "pembuka jalan" untuk menemukan "benang merah" (faktor penjelas) yang dimaksud.

Bowo adalah seorang Aremania, pengamen, ayah dari seorang putri bernama Mayang. Walaupun hanya seorang pengamen (nota bene berpenghasilan tidak menentu), tetapi dalam hal dukungan kepada Arema memperlihatkan sikap yang sangat fanatik tapi beretika. Ketika ditanya apa arti fanatik dengan lugas Bowo menjawab:

Lek ayas Sam, fanatik iku opo yo, pokoke sueneng banget karo Arema, sampek matek lek perlu mbelo Arema terus, tapi kelakuane yo tetep perlu dijogo. Asline yow, ayas gak sepiro seneng lek fanatike arek-arek iku ngawur, sing mecahi koco mobil plat L, padahal durung mesti iku bonek. Terus ngebeki dalanan dadi akeh motor utowo mobil sing gak iso lewat tekok arah berlawanan, sampek-sampek podho wedi lek Arema lagi konvoi ngunu iku. Asline yow gak opo-opo se lek menurut ayas, tapi yo ndelok-ndelok lah, kelakuane dijogo, ben jenenge Arema karo Aremania apik.
Apakah yang membuat Bowo bersikap dan berprinsip seperti itu? Membela Arema sampai mati. Begitu digali lebih dalam ternyata sikap yangditunjukkanBowotersebutlebihmerupakan luapan ketidakpuasan atau ketidakrelaannyajika ada klub sepak bola harus menggunakan dana APBD untuk biaya operasionalnya. ${ }^{8}$ Sementara Arema adalah murni swasta.

Ayas seneng arema soale tekok pendanaane gak nganggo duwite rakyat, terus prestasine yo terus berkembang tambah apik, enek peningkatanlah, dadi gak ngecewakne suportere, iku tambah nggarai ayas seneng banget nang Arema. ${ }^{9}$

Sikap membela atau mendukung klub sepakbola yang tidak mengandalkan dana dari pemeintah (baca: klub swasta) mencerminkan sebuah sikap profesionalismeyang patutdihargai dan diapresiasi. Sebagai seorang pengamen sikap yang ditunjukkan Bowo sangat boleh jadi adalah sebuah bentuk resistensi terhadap klubklub yang mengandalkan dana dari pemerintah agar dapat eksis menjalani setiap pertandingan. Berapa banyak dana yang harus dikucurkan pemerintah daerah (baca: APBD) untuk sebuah klub dalam satu musim kompetisi? Dibandingkan misalnya dana yang demikian besar itu jika dialokasikan untuk pembangunan daerah khusunya penanggulangan kemiskinan dan percepatan pembe-rantasan buta aksara, yang di daerah konon masih tergolong cukup tinggi.

Tipe Aremania yang lain adalah tipe "Loyalitas tanpa Batas". Mereka adalah orang-orang dengan posisi sosial-ekonomipendidikan terbilang cukup. Namun dalam hal memberikan dukungan kepada Arema mereka memiliki loyalitas yang cukup tinggi. Ungkapan "loyalitas tanpa batas" menggambarkan sebuah pengorbanan yang benar-benar total tanpa mengenal batas. "Loyalitas tanpa batas" memang terkesan sangat arogan, karena secara logika segala sesuatu di dunia ini memiliki batasanbatasan tertentu (kecuali kuasa Tuhan). Namun makna terdalam sesungguhnya adalah sebuah perwujudan kecintaan Aremania terhadap Arema sehingga membuat Aremania benarbenar menjaga cinta tersebut dengan sebuah kesetiaan dan pengabdian.

Secara umum loyalitas dimaknai sebagai kesetiaan, pengabdian dan kepercayaan yang diberikan atau ditunjukan yang di dalamnya terdapat rasa cinta dan tanggung jawab untuk 
berusaha memberikan pelayanan dan perilaku yang terbaik (Rasimin, 1988). "Loyalitas adalah kesetiaan, kepatuhan, dan ketaatan" (KBBI, 1990). Loyalitas adalah sebuah kata yang memiliki konsekuensi lebih tinggi dari sekedar solidaritas.

Di dalam Agama Islam, misalnya, loyalitas merupakan masalah yang sangat penting dan ditekankan kewajibannya, karena merupakan salah satu landasan keimanan yang agung, yang dengan melalaikannya akan menyebabkan rusaknya keimanan seseorang sebab loyalitas adalah bagian dari syahadat. Ia merupakan bagian penting dari makna syahadat. Maka, menetapkan "hanya Allah" dalam syahadat tauhid berarti seorang Muslim harus berserah diri hanya kepada Allah, membenci dan mencintai hanya karena Allah, lembut dan marah hanya kepada Allah, dan ia harus memberikan dedikasi maupun loyalitasnya hanya kepada Allah. Bahkan secara literasi, terlihat jelas bahwa dari beberapa kalangan jamaah dari umat Islam, yang dianggap mewakili beberapa suara dan kepen-tingan, terlihat bahwa loyalitas adalah bagian dari aqidah.

Di era postmodern ini mungkin tidak banyak orang memiliki loyalitas. Istilah ini sering digunakan untuk mengindahkan sifat loyal. Kalau ada yang lebih bagus dan menjamin kehidupan untuk apa susah-susah loyal? Setiap orang pasti berorientasi kesuksesan, kenikmatan, keindahan, kenyamanan dan hal-hal menyenangkan lainnya. Segala cara ditempuh termasuk cara-cara instan melalui jalan pintas seperti merampok, korupsi, dan sebagainya. Itu sudah menjadi sifat dasar manusia, selalu mencari kenik-matan dan tidak pernah puas dengan apa yang sudah diperoleh. Pertanyaannya, apakah ada di zaman sekarang ini, di mana urusan ekonomi adalah sesuatu yang urgen, ada orang yang masih setia dan loyal kepada sesuatu yang tidak memberikan kenikmatan secara ekonomi (material)? Sulit dibayangkan jika seseorang bekerja tanpa memperhitungkan gaji. Ketika bekerja seseorang pasti memperhitungkan seberapa besar kualitas dengan kuantitasnya. Tidak mau berlaku adagium besar pasak dari pada tiang, tapi melihat pekerjaan yang dilakukan haruslah sebanding dengan gaji yang daperoleh. Jika sesuai antara pengorbanan dengan hasil yang diperoleh, umumnya seseorang mulai mempertimbangkan loyalitas. Lebih dipertanyakan lagi adalah loyalitas itu justru berlaku dalam sebuah even bernama sepakbola. Ternyata tidak semua orang berpikiran seperti itu. Masih ada orang yang mencintai pekerjaannya meski upah atau gaji yang diperoleh tidak sebanding bahkan jauh dari cukup, tetapi mereka tetap mencintai pekerjaan dan loyal menjalaninya.

Bagaimanamaknaloyalitasyangditunjukkan Aremania dalam mendukung Arema Indonesia ketika bertanding baik kandang maupun tandang? Salah satu ilustrasi dan representasi terlihat pada saat Aremania menunjukkan "ritualnya" dalam mendukung Arema ketika pertandingan melawan Persib berikut ini dapat menggambarkan bagaimana wujud "loyalitas tanpa batas" Aremania.

Kamis sore, 03 Mei 2012 adalah hari pertandingan Arema versus Persib Bandung, sesuai jawal ISL putaran kedua. Sebagaimana diketahui dalam beberapa pertemuan Arema jarang (untuk tidak mengatakan tidak pernah) menang atas Persib Bandung. Kamis sore itu dahaga kemenangan atas Persib Bandung terlampiaskan. Satu kemenangan yang menghapus semua dahaga tepat ketika adzan maghrib berkumandang di seluruh langit Malang Raya. Sebuah hasil yang sangat membahagiakan, karena diraih atas lawan yang memiliki hubungan tidak terlalu baik dengan Arema beberapa tahun terakhir.

Sore hari itu menjadi sore di mana sebuah loyalitas benar-benar dipertaruhkan oleh Arema dan Aremania. Pemain mengawalinya dengan tetap bermain dengan kondisi kembali dikhianati oleh Manajemen. Di tribun, sang dirigen menjadi inspirator hebat, mengelilingi tribun mengajak Aremania bernyanyi, dengan cara merambat di pagar pembatas di tengah kondisi hujan lebat, Yuli Sumpil membangkitkan semangat Aremania, dimulai dari curva sud di sisi Utara, hingga berakhir disinggasana kebesarannya, di depan papan skor yang hadir dengan wajah baru. Itulah makna dari tulisan di kaos baru Arema: Arema Till The End! Dan Aremania membalasnya dengan geloraan semangat yang tidak pernah padam, seperti diakui sang pelatih Suharno, "Aremania telah merontokkan mental pemain Persib". Sebuah bentuk pressure yang sangat diperlukan untuk menolong tim, dan wajib dilakukan Aremania. Nyanyian, dukungan, dan teriakan heroik adalah hal yang wajar dan jamak terjadi dalam sepakbola, dan memang itulah tugas Aremania selaku supporter, sebagaimana Liverpuldian menghancurkan mental Fernando Torres dikandang klub barunya Stanford Bridge setelah pindah ke Chelsea. Itulah wujud loyalitas Aremania, sebuah kesetiaan yang tulus tanpa 
pamrih, sebuah kesetiaan yang tidak dibatasi oleh ruang dan waktu. Itulah makna "loyalitas tanpa batas" yang menjadi semboyan dan komitmen tulus Aremania dalam mendukung Arema Indonesia, yang kemudian menjelma menjadi budaya Aremania hingga saat ini dalam mendukung Arema Indonesia ketika menjalani pertandingan liga sepak bola di Indonesia (ISL), di manapun dan kapanpun.

Ketika digali lebih jauh apa makna "loyalitas tanpa batas" dalam pandangan Aremania? Nilai dasar apakah yang dijadikan pijakan sehingga tergolong ke dalam tipe Aremania yang berbudaya "loyalitas tanpa batas" dalam mendukung Arema?

Mochammad Zulham Efendi, Aremania dari Bululawang Malang, mahasiswa, berusia 28 tahun, misalnya, memang terlihat sesuai dengan sebutan "loyalitas tanpa batas" dalam hal mendukung Arema. Jika sebagian besar temantemannya yang sama-sama kuliah memilih lebih mementingkan kuliah daripada mendukung Arema, tidak demikian dengan Zulham. Di selasela kesibukan kuliah, dia tetap mendukung Arema dengan cara datang langsung ke stadion Kanjuruhan dengan resiko harus meninggalkan kuliah demi Arema. Apa yang membuatnya bersikap demikian? Adakah faktor lain selain faktor kebanggaan menjadi suporter Aremania sebagaimana lazim dipahami para suporter Aremania?

Mulai suka dan aktif terlibat sejak SD. Kami satu keluarga suka sama Arema dan Aremania. Selain suporter itu memberikan support kepada pemain, ada kebanggaan menjadi supporter Aremania. Sebagai orang Malang ya bangga terhadap komunitas Aremania karena ada faktor kebersamaan. Aremania bukan organisasi tetapi sebuah bentuk kebersamaan, ada rasa memiliki. Karena itu apapun yang terjadi ya harus didukung apalagi ketika Arema bertanding. KemenanganAremaadalahjugakemenangan Aremania dan kekalahan Arema adalah juga kekalahan Aremania. Arema adalah simbol kebanggaan dan harga diri Aremania. ${ }^{10}$

Loyalitas tanpa batas lahir dari sebuah perjuangan tanpa mengenal kata berhenti. Loyalitas tanpa batas dalam pemahaman sebagian Aremania adalah dukungan yang diberikan kepada Arema tanpa mengenal batas-batas keterbatasan manusia, termasuk ke manapun Arema bertanding harus selalu diikuti dengan berbagai resiko yang harus dianggung.
Oleh karena itu, jika ada Aremania yang memilih untuk tidak ikut Tour Aremania dalam rangka mendukung Arema akan dikatakan "Woo gak loyal, gak militan!"11 Demikian kata-kata yang selalu meluncur dari mulut Aremania ketika menyaksikan beberapa Aremania tidak ikut dalam Tour tersebut.

Berbeda dengan tipologi budaya "fanatik tapi beretika" dan "loyalitas tanpa batas", kelompok yang ketiga adalah kelompok Aremania bertipologi "tidak narsis tapi selalu eksis". Mereka tidak dapat dimasukkan ke dalam kategori tipologi "fanatik tapi beretika", juga tidak dapat dikelompokkan ke dalam kategori tipologi "loyalitas tanpa batas". Oleh karena itu mereka disebut tipologi "tidak narsis tapi selalu eksis". Orientasi dan semangat untuk mengoptimalkan sumber-sumber daya yang dipunyai berada pada tingkat sedang, tidak terlampau tinggi sebagaimana kecenderungan tipologi yang pertama, namun juga tidak serendah tipologi yang kedua.

Sosok Aremania pada tipologi yang ketiga yakni "tidak narsis tapi selalu eksis" tercermin pada Nanang, pengusaha catering, berusia 40an tahun, ayah 2 anak. Dia tergolong cukup rajin menonton pertandingan Arema di Malang (pertandingan kandang), serta tidak terdapat keengganan terhadap pertandingan Arema. Sebagai pengusaha catering di Malang Raya tidak menghalangi Nanang untuk selalu setia menonton pertandingan Arema. Padahal usaha cateringnya tergolong sukses. Yang terlihat dipedulikan Nanang adalah pertandingan Arema. Akan tetapi jika Arema bermain di luar kandang Nanang tidak akan ikut Tour sebagaimana lazimnya Aremania yang lain. Ketika ditanyakan mengapa tidak ikut Tour bersama Aremania yang lain? Dengan lugas Nanang menjawab:

Tidak boleh terlampau berlebihan, apa pun juga Menonton ya menonton

$$
\begin{aligned}
& \text { Kerja ya kerja } \\
& \text { Bila Arema main di kandang, ya nonton } \\
& \text { Bila Arema main di luar kandang, ya kerja }{ }^{12}
\end{aligned}
$$

Kutipan tersebut di atas mengisyaratkan bahwa memberikan dukungan terhadap sebuah tim kesayangan tidak boleh berlebihan sebagaimana tampak pada tipologi pertama dan kedua, tetapi penuh perhitungan. Tipologi inilah yang dalam penelitian ini dimasukkan ke dalam tipologi yang ketiga yakni tipologi "tidak narsis tapi selalu eksis". Boleh dilakukan sepanjang dapat dijangkau atau tidak menghambat 
pekerjaan. Tetapi kalau menghambat atau menghalangi pekerjaan bahkan meninggalkan pekerjaan demi membela atau mendukung Arema lebih memilih bekerja ketimbang menonton dan mendukung Arema. Dikatakan penuh perhitungan karena mendukung Arema dengan cara harus mengikuti ke mana pun Arema bertanding akan sangat berat dan mengganggu pekerjaan mereka. Tipologi yang ketiga ini tidak primordial terhadap Arema tetapi selalu eksis. Mereka selalu datang untuk memberikan dukungan kepada Arema jika pertandingan kandang.

Sosok yang demikian bukan tipe suporter profesional. Mereka akan datang menyaksikan pertandinganjika yang bertanding adalah Arema Indonesia. Tidak peduli apakah lawan yang dihadapi Arema termasuk tim papan atas atau bukan, mereka akan datang untuk memberikan dukungan kepada Arema. Kebanggaan menjadi Aremania adalah sebuah keniscayaan. Arema are more than just a football club. They are a way of life. They are the St Pauli of Indonesia. A culture with in a culture. Satu Iiwa, one heart or one soul. Arema is rough and ready. It's Satu Jiwa, one soul, it's Arema or nothing. It's a five hour walk home after a home game. It's football of the people, not the marketing men and it's real.

Mengapa kategori berdasarkan komitmen jiwa Aremania yakni "fanatik tapi beretika","loyalitas tanpa batas", dan "tidak narsis tapi selalu eksis" tersebut dimasukkan dalam kerangka budaya Aremania? Bukankah ia lebih merupakan sebuah komitmen jiwa yang ada di dalam hati setiap Aremania? Jawabannya dapat dikembalikan kepada pola pemikiran Aremania yang menempatkan ketiga komitmen itu sebagai bagian dari upaya membangun identitas dalam konstruksi sosial Aremania di jagat sepakbola Indonesia. Jadi, komitmen dukungan kepada Arema bukanlah untuk komitmen itu sendiri, melainkan komitmen tersebut melekat di dalam diri Aremania untuk suatu tujuan tertentu yakni identitas Aremania. Ia berposisi sebagai niat yang terbenam, melekat, dan sebagai bagian integral budaya suporter sepakbola. Ia ikut sebagai pemberi orientasi yang mewarnai sikap Aremania terhadap budaya suporter sepakbola ketika memberikan dukungan kepada Arema. Sebab, di balik sikap terhadap budaya suporter sepakbola senantiasa ada "niat" untuk apa atau identitas macam apa yang ingin dibangun oleh Aremania.

\section{SIMPULAN DAN SARAN}

\section{Kesimpulan Hasil Penelitian}

Bagian ini dimaksudkan untuk menyajikan kesimpulan umum penelitian ini berdasarkan hasil dan pembahasan hasil penlitian. Ada tiga kesimpulan yang bisa dikemukakan. Pertama, Aremania memiliki karakteristik sebagaimana suporter sepak-bola pada umumnya. Hal ini sesuai dengan konsepsi suporter sepakbola yang menyatakan bahwa suporter sepakbola adalah juga penonton namun berbeda karena memiliki tingkat fanatisme terhadap klub yang tinggi. Namun demikian, adalah salah apabila menyamakan Aremania dengan suporter sepakbola lainnya. Fanatisme Aremania berbeda dengan fanatisme suporter sepakbola yang lain. Fanatik tapi beretika adalah budaya suporter yang ingin dibangun oleh Aremania. Fanatik tetapi tidak boleh sampai pada tingkat merugikan orang lain. Ada penghormatan terhadap nilai-nilai kemanusiaan sekaligus menjaga kehormatan dan martabat sebagai orang Malang.

Kedua, berdasarkan perspektif emik, suporter sepakbola memiliki cakupan makna yang lebih luas dari sekedar menonton sepakbola. Mencurahkan tenaga dan pikiran, memaksimalkan sumber-sumber daya yang dipunyai untuk mendukung klub kesayangannya juga dimaknai sebagai budaya suporter sepakbola. Bahkan meluangkan waktu sertajiwaraga untuk mendukung tim kesayangannya juga diartikan sebagai budaya suporter sepakbola.

Ketiga, sekalipun sepakbola dan Arema itu pentingbagiorangMalang, namunkeutamaannya lebih bersifat instrumental yakni lebih bersifat penjamin kebanggaan dan termasuk salah satu sumber pengangkat kehormatan dan martabat orang Malang. Hal itu sejalan dengan etos budaya orang Malang yang "menomorsatukan" soal kehormatan dan martabat.

\section{SARAN}

Satu corak saran teoretis yang bersifat hipotetik layak diajukan. Secara teoretis para suporter sepakbola Aremania akan senantiasa kritis terhadap setiap bentuk fanatisme yang berlebihan apalagi sampai pada tingkat perbuatan yang merugikan orang lain seperti tindakan-tidakan anarkis. Sikap kritis tersebut tidak terlepas dari kebutuhan dan kepedu- 
lian Aremania terhadap pandangan dan etos budaya suporter sepakbola yang dibangun oleh Aremania berdasarkan karakteristik orang Malang dan tuntutan untuk lebih mengedepankan penghormatan terhadap nilai-nilai kemanusiaan yang universal.

Sementara, saran praktis lebih berkenaan denganisukeberlangsungansosio-budaya.Kasus di tingkat mikro (komunitas Aremania) yang ditemukan dalam penelitianinimenghamparkan contoh kongkret keberlangsungan sosiobudaya (socio-culural-viability) karena senantiasa berlangsung kompatibilitas antara bias budaya di dunia ide dan preferensi di tingkat praktik sosial sehari-hari. Keberlangsungan sosiobudaya semacam itu tentu juga suatu kebutuhan untuk terwujud pada tingkat yang lebih makro, termasuk juga di level nasional. Jika tidak bias budaya yang diproklamasikan sebagai pandangan hidup bangsa bisa laksana "sangkar emas" yang dipenuhi "burung murahan", yang pada gilirannya akan membumihanguskan nilai "keemasan" sangkar itu sendiri. Ini suatu tantangan besar bagi setiap abdi Negara dan bangsa terutama mereka yang berke-cimpung di dunia olahraga sepakbola. Kajian-kajian mendalam sangat diperlukan, baik di tataran teoretis-konseptual maupun pada tataran faktual-empirik. Dalam konteks ini, para ilmuwan disarankan mengambil peran sesuai dengan tugas utama cendekiawan: mencari dan membela kebenaran. Beberapa keterbatasan yang belum terselesaikan dalam penelitian ini disarankan untuk dikaji dan diteliti lebih lanjut.

\section{DAFTAR RUJUKAN}

Baudrillard, J. 1998. The Consumer Society: Myths and Structures. London: Sage.

Bourdieu, P. 1993. "How Can One Be A Sports Fan?" Dalam Simon During (Ed.). The Cultural Studies Reader. London: Routledge.

Brown, A. (Ed.). 1998. Fanatics! Power, Identity, and Fandom in Football. London \& New York: Routledge.

Chambers, I. 1986. Popular Culture: The Metropolitan Experience. London \& New York: Methuen.

Faisal, S. 1990. Penelitian Sosial: Dasar-dasar dan Aplikasi. Malang: YA3.

1996. Pengumpulan dan Analisis Data Penelitian Kualitatif. Makalah Disajikan dalamSeminar danLokakarya Regional. Malang: FPIPS-IKIP Malang.
Galeano, Eduardo. (tt.). Soccer in Sun and Shadow. (Online) (http://thebrowser. com/ recommended/soccer-sun-andshadow-by-eduardo-galeano, diunduh 11 April 2011).

Giddens, A. 1984. The Constitution of Society: Outline of the Theory of Structu-ration. Berkley: University of California Press.

Huberman, A . M. dan Matthew B. Miles. 1994. "Data Management and Analysis". Dalam Norman, Denzin K dan Loncoln Yvonna S (Ed.). Handbook of Qualitative Research. California: Sage Publications.

King, A. 1997. "The Postmodernity of Football Hooliganism". In The British Journal of Sociology, 48 (4): 576-593.

Schirato, T. 2007. Understanding Sports Culture. Los Angeles, London, New Delhi, Singapore: Sage.

Spradley, J. P. 1979. The Ethnographic Interview. New York: Holt, Reinhart and Watson.

Spradley, J.P. 1970. You Owe Yourself a Drunk: An Ethnography of Urban Nomads. Boston: Little, Brown.

Spradley, J.P. 1972. Foundations of Cultural Knowledge. Dalam Culture and Cognition: Rules, Maps, and Plans, ed. J.P. Spradley, 3-40. San Francisco: Chandler. 400 pp.

Wallace, A.F.C. 1965. "Driving lo Work". Dalam Context and Meaning in Cultural Anthropology, ed. M.E. Spiro. Glcncoc, 111.: Free Press.

Wallace, A.F.C. 1970. Culture and Personality. New York: Random House. 2nd ed.

Wawancara dengan Mohammad Hariyadi atau Nanang (04 Januari 2012)

Wawancara dengan Yuli Sugianto atau Yuli Sumpil (29 Maret 2012).

Wawancara dengan Bowo (08 September 2012).

Wawancara dengan Mochammad Zulham Efendi (12 September 2012).

\section{(Endnotes)}

1 Soccer in Sun and Shadow. Publikasi online pada situs: http://thebrowser.com/ recommended/ soccer-sun-and-shadow-byeduardo-galeano, diunduh 11 April 2011.

2 Anthony King, "The Postmodernity of Football Hooliganism". Dalam The British Journal of Sociology, Vol. 48, No. 4 (Desember, 1997), hal. 576-593). 
3 Wawancara dengan Yuli Sugianto atau Yuli Sumpil (29 Maret 2012) sebelum pertandingan Arema vs Persiwa Wamena). Dia dikenal sebagai Dirigen Aremania sejak 1998.

4 Kata "Sam" adalah kebalikan dari kata "Mas" dalam bahasa walikan Arek Malang. Kata ini sudah menjadi kata sapaan yang digunakan arek-arek Malang dalam komunikasi keseharian mereka.

5 Wawancara dengan Mochammad Zulham Efendi (28 tahun) Aremania dari Bululawang Malang (12 September 2012).

6 Cultural studies menjadikan identitas sebagai salah satu tema penting kajiannya, dengan menun-jukkan signifikansi sosial dan kultural identitas itu sendiri sekaligus memperlihatkan kontradiksi-kontradiksi internalnya.
7 Roger M. Keesing, Teori-teori Budaya. Buku yang dirujuk merupakan terjemahan dari Theories of Culture: Annual Reviewof Anthropology (1974).

8 Bowo tidak secara jelas menunjuk kesebelasan atau klub mana yang dimaksud. Tapi dapat dipastikan bahwa yang disindir Bowo adalah Persema Malang.

9 Hasil wawancara dengan Bowo (8September 2012).

10 Hasil wawancara dengan Mochammad Zulham Efendi (12 September 2012).

11 Hasil pengamatan saat Aremania melakukan Tur ke Jakarta mendukung Arema bertanding melawan Persija (15 Mei 2012). Jadwal pertandingan tandang putaran kedua Arema versus Persija, 17 Mei 2012.

12 Wawancara dengan Nanang (04 Januari 2012). 
46 | Harun Ahmad, Pemahaman tentang Budaya Supporter Sepakbola ... 